\title{
Do smallholder farmer-led seed systems have the capacity to supply good-quality, fungal-free sorghum seed?
}

Kudzai Kusena ${ }^{1,2^{*}} \mathbb{D}$, Rachel Wynberg ${ }^{1}$ and Claid Mujaju ${ }^{3}$

\begin{abstract}
Local seed systems that are developed, managed and maintained by farmers are a fundamental practice in smallholder crop production, supporting more than $80 \%$ of farmers in sub-Saharan Africa and feeding more than $70 \%$ of its population. The resilience of such systems is under threat from poverty, climate change, drought, increased pests and diseases, over-promotion of modern crop varieties, change of lifestyles and restrictive seed policies. The system continues to be maligned as having inferior quality, yet few studies support this assertion. This study aims to fill this research gap by evaluating 60 sorghum seed samples collected from smallholder farmers in Uzumba-MarambaPfungwe and Chimanimani districts of Zimbabwe. We investigated the effect of farmer-led seed management practices (e.g. seed acquisition and seed storage practices) on farm-derived sorghum seed quality (moisture, germination and fungal incidences). We found farmers using diverse seed sources and seed storage practices. Seeds were typically of good quality in that their storage moisture content was low, their germination was high, and fungal incidences were low. Seed sourced from local markets, non-governmental organizations and other farmers had germination and moisture standards that met the sorghum certification standards in Zimbabwe. However, few samples obtained from the relatives and government failed to meet the germination and/or moisture certification standards. We detected low incidences of fungi (Aspergillus flavus, Aspergillus niger, Curvularia lunata, Fusarium sp. and Penicillium sp.) in sorghum seed samples tested and in particular Fusarium sp., which is the most economic important fungus in sorghum production. We conclude that farmer-led seed systems have the capacity to supply seeds of good quality and recommend that such systems should be recognized and promoted to meet the ever-evolving needs of smallholder farmers in sub-Saharan Africa.
\end{abstract}

Keywords: Access to seed, Seed security, Seed storage, Seed health

\section{Background}

There is a wide recognition that the global balance for food production and environmental sustainability is tipping [1], with future food and nutritional security threatened by the unsustainable intensification and expansion of industrial agriculture [2-4]. Increased attention is being given to alternative ways of crop production, based on traditional smallholder farming systems such as

*Correspondence: kudzaikusena@yahoo.com; ksnkud0001@myuct.ac.za

${ }^{1}$ Department of Environmental and Geographical Sciences, University

of Cape Town, Rondebosch, Cape Town 7700, South Africa

Full list of author information is available at the end of the article agro-ecology ${ }^{1}$ that promote biodiversity, reduce reliance on external chemical inputs and sustain year-round yields [3]. The International Assessment of Agricultural Knowledge, Science and Technology for Development (IAASTD) for example has called for redesigning of the Global Food System in support of small-scale agro-ecological systems [4], whilst World Bank and the International Panel of Experts on Sustainable Food Systems (IPES) has noted smallholder farming to be the main pathway to enhancing productivity, profitability,

\footnotetext{
${ }^{1}$ Agro-ecology is the application of ecological concepts and principles to the design and management of sustainable food systems that are environmentally sound, highly productive and economically viable [42].
} 
environmental sustainability and poverty reduction in Africa [5, 6].

Several scholars (e.g. $[7,8])$ corroborate that smallholder farming systems in Africa have the potential to sustainably provide livelihoods, food and nutritional security to most of the continent's population. Yet the success of smallholder agriculture is largely determined by the viability and resilience of local seed systems. Such systems are estimated to account for $60-100 \%$ of seed materials planted by smallholder farmers in Africa [9-11] and are envisaged to remain the dominant seed source in Africa in the foreseeable future $[11,12]$.

Seed is the basic unit of crop production [13], and its quality is a primary determinant of yield and nutrition [9]. Yet seed is not only a vehicle for promoting productivity, nutrition and resilience, but also an entry point for achieving multiple development goals [11]. The practices that farmers use to produce, procure, save, exchange and sell seed define what we refer to as farmer-led seed systems, sometimes described in the literature as informal, traditional [14], local [15] or farmer-led or managed [16, 17]. Although such seed systems continue to be maligned as having inferior quality, few studies support this assertion. By evaluating 60 sorghum samples collected from farmers in the Uzumba-Maramba-Pfungwe (UMP) and Chimanimani districts of Zimbabwe, this study aims to fill this research gap by investigating how different seed sources and storage practices influence seed quality (storage moisture content, germination quality and fungal incidence levels).

Sorghum is the fifth most important cereal crop in the world after rice, wheat, corn and barley and the second most important crop (after maize) in sub-Saharan Africa [18]. It is also the main cereal food for over 750 million people living in semi-arid tropical regions of Africa, Asia and Latin America [19]. Sorghum is drought tolerant and has high and stable water use efficiency, tolerating temporal waterlogging and heat, whilst endowed with high germplasm variability and nutrition [20]. The crop is recommended for special diets such as for diabetics and infants since it is rich in essential minerals. It is also used as a livestock feed, for industrial manufacture of ethanol, traditional brewing, house thatching and fencing [21]. For these reasons, we focus on sorghum seed as an entry crop to evaluate the resilience ${ }^{2}$ of farmer-led seed systems in smallholder farming communities of Zimbabwe.

Current levels of poverty in sub-Saharan Africa, coupled with the adverse effects of climate change and the high cost of agricultural inputs, suggest that crop farming in smallholder farming communities is likely constructed

\footnotetext{
2 The capacity of a system to absorb shocks and stress, and re-organize so as to maintain and strengthen seed security over time [43].
}

around farmer-led seed systems [12]. Such systems are often criticized because seeds in their circulation are not tested for quality [22]. In contrast, the formal seed system is not always compatible with the diverse seed requirements for smallholder farming systems [23]. Farmer-led seed systems have proved to be resilient, as the systems continue to function without support from known quality assurance institutions $[11,24]$.

Pests and diseases, poor harvesting, handling and storage are however major challenges to seed quality. The study thus investigated fungal infections, germination and moisture qualities as key determinants of seed quality. Fungal infections cause seed moulding, a condition caused by parasitic and/or saprophytic interactions of numerous fungal species. Moulding reduces yield and affects seed viability, kernel weight and nutritional quality in sorghum $[25,26]$. Although we screened five different fungal species, Fusarium sp. are the most economically important fungi in sorghum [27], causing diseases such as damping off, seed rot, head blight, root and stalk rot and seedling blight [25].

In addition, fungal grain infections also produce mycotoxins. These secondary toxic metabolites contaminate food and feed produced from infected sorghum. Mycotoxins have a huge impact on human and animal health. They cause many adverse health effects such as the induction of cancer and mutagenicity, as well as oestrogenic, gastrointestinal and kidney disorders, with some being immunosuppressive [28].

This study, which was done in Zimbabwe, provides a classic example of a country with a plethora of social, economic and ecological perturbations. The economy of Zimbabwe collapsed in the first decade of the twenty-first century, rendering its currency obsolete and crippling agricultural production [29]. This affected seed security in the context of failing formal markets, constrained disposable household income and increased vulnerability to the effects of climate change. This backdrop of a 'failed system' presents a fitting environment for investigating the resilience of farmer-led seed systems in the sense of its capacity to effectively supply viable and fungal-free quality seeds. Although this context is not unique to Zimbabwe, many countries in the world can learn from this experience.

\section{Methods}

An interdisciplinary research approach was used, with data collected through a combination of qualitative and quantitative methods including household surveys, key informant interviews, participatory observations and laboratory experiments. The study was undertaken in smallholder farming communities of Uzumba-Maramba-Pfungwe (UMP) and Chimanimani districts of 
Zimbabwe. UMP is located in Mashonaland East Province, whilst Chimanimani is in Manicaland Province. The study districts are spatially characterized by diverse natural agro-ecological regions, and our specific study areas were situated in the natural agro-ecological region IV [30]. This region receives low mean annual rainfall of $650-800 \mathrm{~mm}$ with mean annual temperature of $18-24{ }^{\circ} \mathrm{C}[30,31]$. These areas are highly prone to the effects of climate change, drought, poverty and food and nutritional insecurity. They have poor soils and are in general deemed unsuitable for crop production. Nonetheless, farming communities in these areas depend on rain-fed subsistence agriculture for their livelihoods.

\section{Semi-structured household questionnaire}

A household questionnaire was administered to capture from where farmers source their sorghum seeds and how they store their seeds (see Appendix 1). A total of 213 households (approximately 10\% of the total households in selected wards) from both districts (96 households in UMP from Wards 4 and 5; 117 households in Chimanimani from Ward 3) participated in the survey, comprising 12 villages from UMP and 6 villages from Chimanimani. A mixture of purposive and stratification sampling procedures was used to select the wards and villages. Villages falling in natural agro-ecological zone IV and highly dependent on dry land agriculture were selected. The process of selecting wards and villages was informed through consulting farmers, extension workers and traditional leaders in the respective study communities. Table 1 presents the GPS coordinates for participating wards and villages. Systematic random sampling was done to select the participating households. Sample size was used to calculate sampling intervals per village. The first house was randomly selected, and the proceeding households were selected by skipping households within the sampling interval.

\section{Sorghum seed sample collection}

Whilst administrating the semi-structured questionnaires the study also carried out a sorghum seed collection. This took place at the onset of the 2015/2016 cropping season. A $500-\mathrm{g}$ sorghum seed sample was collected from interviewed household that had sorghum seed they could share. Collected samples were modest mainly because the previous cropping season $(2014 / 2015)$ was a drought season and communities were both seed and food insecure. The sample size was determined by the seed quantity required to carry out germination and seed health tests following International Seed Testing Association (ISTA) standards [32].
Table 1 Summary GPS coordinates sampled villages in Uzumba-Maramba-Pfungwe and Chimanimani districts

\begin{tabular}{llll}
\hline District (wards) & Villages & Longitude $\left(^{\circ}\right.$ ) & Latitude $\left(^{\circ}\right)$ \\
\hline Chimanimani (Ward 3) & Musweweshiri & -19.57221 & 32.50563 \\
& Zvekuitirwa & -19.59800 & 32.50558 \\
& Jinga & -19.48473 & 32.54776 \\
& Nechitima & -19.57093 & 32.54776 \\
& Mubururu & -19.5597 & 32.54932 \\
& Namire & -19.53334 & 32.59996 \\
Uzumba-Maramba- & Chinyama & -16.87028 & 32.05193 \\
Pfungwe (Ward 4) & Chibundu & -16.89817 & 32.0786 \\
& Chiunye & -16.88045 & 32.08931 \\
& Chikomba & -16.90036 & 32.09512 \\
& Karimatsenga & -16.94273 & 32.09894 \\
& Masendeke & -16.99487 & 32.16199 \\
Uzumba-Maramba- & Mupande & -16.92679 & 32.08612 \\
Pfungwe (Ward 5) & Chidhakwa & -16.97258 & 32.05509 \\
& Nyabvedzi & -16.99958 & 32.03926 \\
& Sanzu & -16.94812 & 32.160212 \\
& Chitiyo & -17.00071 & 32.09524 \\
& Togarepi & -16.98557 & 32.10571 \\
\hline
\end{tabular}

Points were taken using Garmin GPS (Model eTrex, and Manufactured by Garmin International Inc., USA)

Sixty sorghum seed samples were collected from smallholder farmers in UMP (27 samples) and Chimanimani (33 samples) districts. Upon collection, samples were packed in muslin cloth bags, labelled and couriered in cardboard boxes to the National Gene Bank of Zimbabwe (NGBZ). At the NGBZ samples were stored in a cold room (Uniblock Zanotti Model MAS221N02G, Mantova, Italy) at $15{ }^{\circ} \mathrm{C}$ and $12 \%$ humidity for storage before commencing laboratory experiments.

\section{Germination tests}

Germination tests were done following the International Seed Testing Association (ISTA) standards [32] at the Department of Research and Specialist Services (DR\&SS), Seed Services Institute (SSI), Harare, Zimbabwe. The SSI is mandated to regulate national formal seed certification in Zimbabwe and hosts a seed-testing laboratory, which is accredited to ISTA.

For germination tests, 50 seeds were taken at random from each sample and planted in 4 replicates on sterilized sand. A Memmert (Model SFE400-800, Schwabach, Germany) oven was used to sterilize the sand by baking it for $8 \mathrm{~h}$ at $220{ }^{\circ} \mathrm{C}$. The planted seeds were placed in a germination chamber (Rootes tempair, Model CCP/1752491CSR, Kent, England) at a temperature of 
$23{ }^{\circ} \mathrm{C}$; relative humidity of $50 \%$ and under constant daylight florescent lighting (Osram L36W880 SKYWHITE) for 10 days. The germination percentage was determined by the percentage ratio of normal seedlings that emerged after the 10-day incubation period and sorghum total seeds planted.

\section{Moisture tests}

A hand-held non-destructive grain moisture metre (DRAMINSKI TwistGrain, Olsztyn Poland; accuracy$\pm 0.5 \%$ for normalized grain) was used to test seed storage moisture content on site. A sorghum sample was drawn from farmers' storage facilities and filled into the instrument's measuring screw cap (the cap carries sample volume of $90 \mathrm{ml}$ ). The cap was screwed tightly back on the moisture tester with assistance of a buzzer indicating the required seed compression. After the buzzer signal, we selected sorghum on the instrument measurement menu and then pressed ok to measure moisture content. Moisture content displayed on the instrument monitor was then recorded on the seed collection questionnaire. The study adopted the formal seed certification standards for sorghum (germination $80 \%$ and moisture content 12.5\%) to benchmark the performance of farmer-led seed storage practices. These standards are stipulated in the seed certification schedule of the Seed Act (Chapter 19:13) of Zimbabwe.

\section{Storage moulding fungi tests}

Sixty sorghum samples (27 and 33 samples for UMP and Chimanimani, respectively) were screened for five important fungal species causing moulding and seed-borne diseases (Aspergillus flavus, Aspergillus niger, Curvularia lunata, Fusarium sp. and Penicillium sp.). Screening was done at the DR\&SS, Plant Protection Research Institute (PPRI), Harare, Zimbabwe, according to ISTA 1996 seed health test standards. In order to understand the occurrence and intensity of fungal infections on sorghum seed circulating in farmer-led seed systems the study adopted the use of relative preponderance (RP) and percentage incidence (PI) indices. RP is the percentage ratio of the number of sorghum samples in which a fungus was encountered against the total number of samples tested. PI is the percentage ratio of the total number of individual seeds (per replicate) in which the fungus was encountered against the total number of seeds tested.

The blotter test [33] was used to screen for A. flavus, A. niger, C. lunata, Fusarium sp. and Penicillium sp. Four replicates of 20 sorghum seeds were placed manually using forceps on a well-moistened (sterilized water) absorbent filter paper, using three layers to provide enough moisture for the duration of the test. The seeds were placed in an incubator (Model WTC BINDER-970962, Tuttlingen, Germany) under near-ultraviolet light in alternating cycles of 12-h light/darkness for seven days at $22{ }^{\circ} \mathrm{C}$. After incubation, fungi that developed on each seed were identified using a stereo microscope (Model aus Jena, German Democratic Republic) and compound microscopes (Vickers Instrument Model 750338, England).

\section{Statistical analysis}

The survey descriptive data and the analysis of variance for seed germination and seed health test were computed using STATA (StataCorp. 2015. Stata Statistical Software: Release 14. College Station, TX: StataCorp LP).

\section{Results}

Distribution of seed storage moulding fungi on sorghum seed circulating in farmer-led seed systems

Sorghum was found to be an important crop and was grown by 76 and $74 \%$ of farmers interviewed in UMP $(n=96)$ and Chimanimani $(n=117)$ districts, respectively. We found A. flavus to be the most common species infecting sorghum seed samples (93\% screened positive, $n=60)$ and Penicillium sp. to be the least common species $(10 \%$ screened positive $n=60)$. A . niger recorded the highest mean percentage incidence (28\%) and Penicillium sp. the least mean PI of $0.3 \%$ (Fig. 1). A. flavus was encountered in 56 samples with PI varying between 0.8 and $40 \%$. A. niger was recorded in 52 samples, and PI ranged from 0.8 to $99.2 \%$. C lunata screened positive in 44 samples, and PI varied between 1.6 and $33.6 \%$. Fusarium sp. was found in 32 samples, and PI ranged from 0.8 to $10.8 \%$. Penicillium sp. was found in 6 samples, and PI varied from 0.4 to $4.8 \%$.

We found that more than half of the tested sorghum seed samples recorded incidence levels below $10 \%$ (Fig. 2). A. niger showed wide spread incidence levels, with the highest incidence of $99 \%$.

\section{Effects of different seed sources used in farmer-led seed systems on sorghum seed quality}

The survey identified six different sources of sorghum seed supply used by farmers in UMP $(n=96)$ and Chimanimani $(n=117)$ districts, namely other farmers, relatives, non-governmental organizations (NGOs), government, local markets and agro-dealers (Fig. 3). The 'other farmers' seed source was defined as that whereby neighbouring farmers shared their seed for free with an understanding that they could benefit in times of scarcity. The 'relatives' category was characterized by seed 


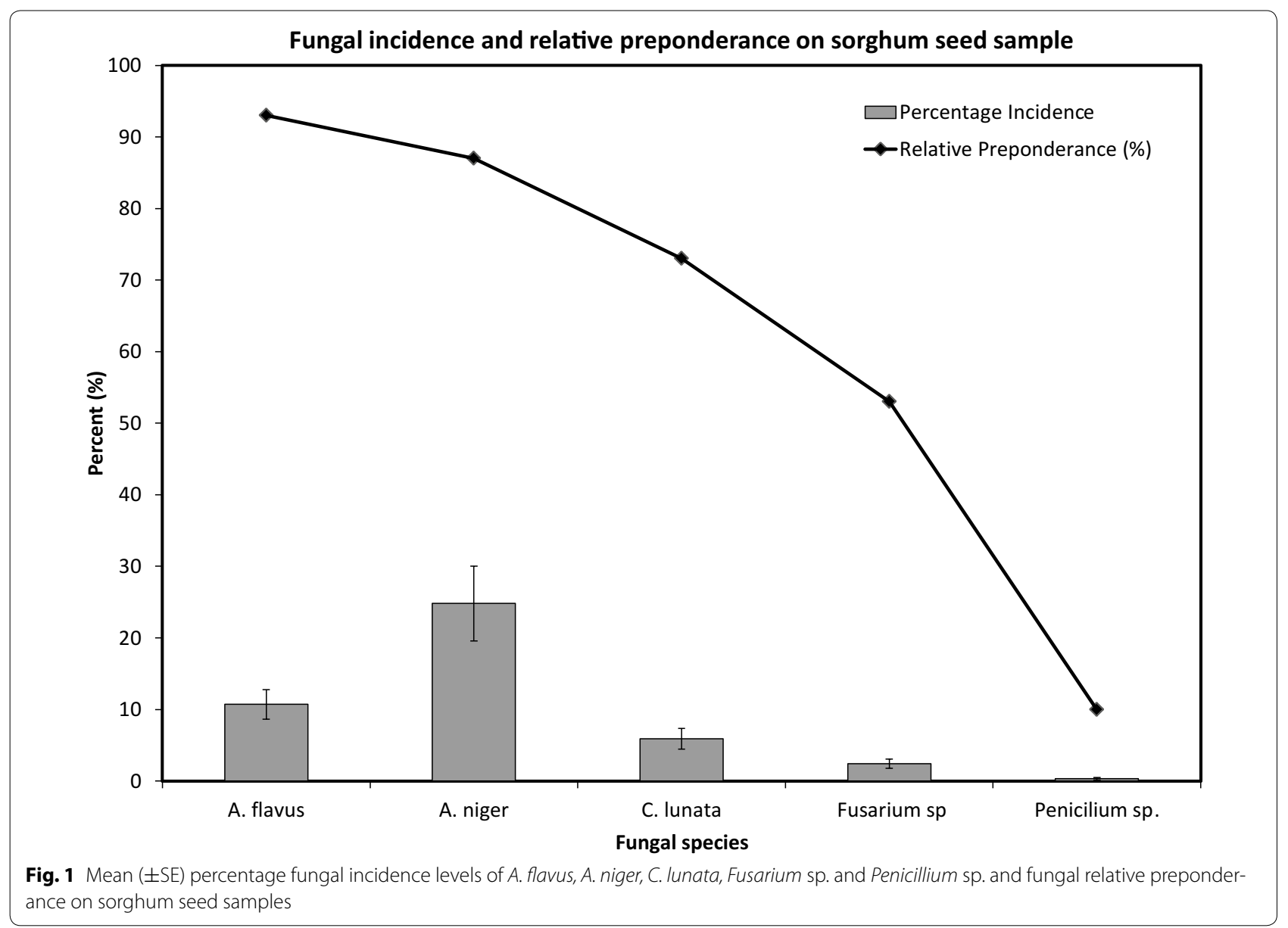

exchanged between relatives as a gift upon visiting each other or for traditional purposes such as when a bride is given seed by her and her groom's parents to start up a family. 'Local market' was characterized by transactions to access seed, through barter or cash. These definitions agree with the narrative of Louwaars and de Boef [9] on informal seed networks. The categories of 'NGO' and 'government' were mainly characterized by seed given to farmers free or on contract. Agro-dealers referred to the shops from where farmers accessed certified seed.

The highest RP was recorded in sorghum seed samples acquired through other farmers, whilst the least RP was detected in samples sourced through local market for the screened fungi (Fig. 4). The 'other farmers' and 'relatives' seed sources recorded the highest mean PI for C. lunata (5\%, respectively); seed samples accessed through NGOs recorded the highest mean PI for A. flavus (16\%) and A. niger (41\%). Penicillium sp. was absent in all samples except for those sourced from other farmers which had RP 9\% and mean PI 1\%. RP for Fusarium sp. (the most important economic fungus in sorghum production) ranged from 0 to $18 \%$, and its mean PI ranged from 0 to $10.8 \%$.

\section{Effects of different farmer-led seed storage facilities on sorghum seed quality}

The survey found that farmers were using four different seed storage facilities, namely sacks, kitchen ceilings, plastic containers and granaries (Fig. 5). Sacks included bags made out of polythene fibre or cotton. Kitchen ceilings meant sorghum seed hung above smoking fire in traditional cooking rooms/huts. Plastic containers referred to any storage facility made up of plastics. Granaries meant traditional seed storage structures. Sacks were the most used storage facilities, whilst traditional granaries were the least used storage facilities in the study areas. We observed that vermin, which did not seem to bother the farmers who claimed that the resulting holes, helped to ventilate the seeds, pilfered most of the sacks and plastics. 


\section{Boxplot for fungal incidence levels in sorghum seed samples}

Penicillium

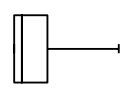

Fusarium

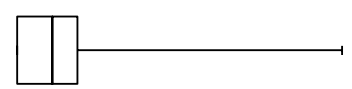

C. lunata

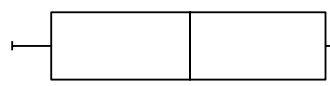

A. niger

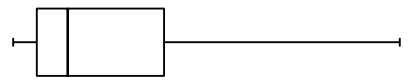

A. flavus

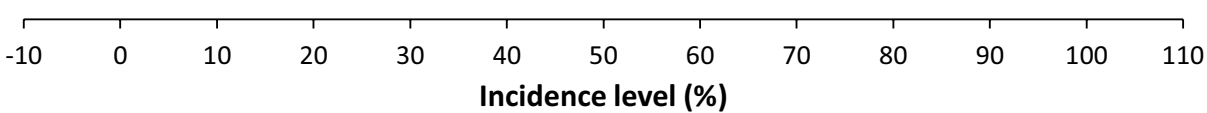

Fig. 2 Box plot of fungal incidences (A. flavus, A. niger, C. lunata, Fusarium sp. and Penicillium) on sorghum seed samples

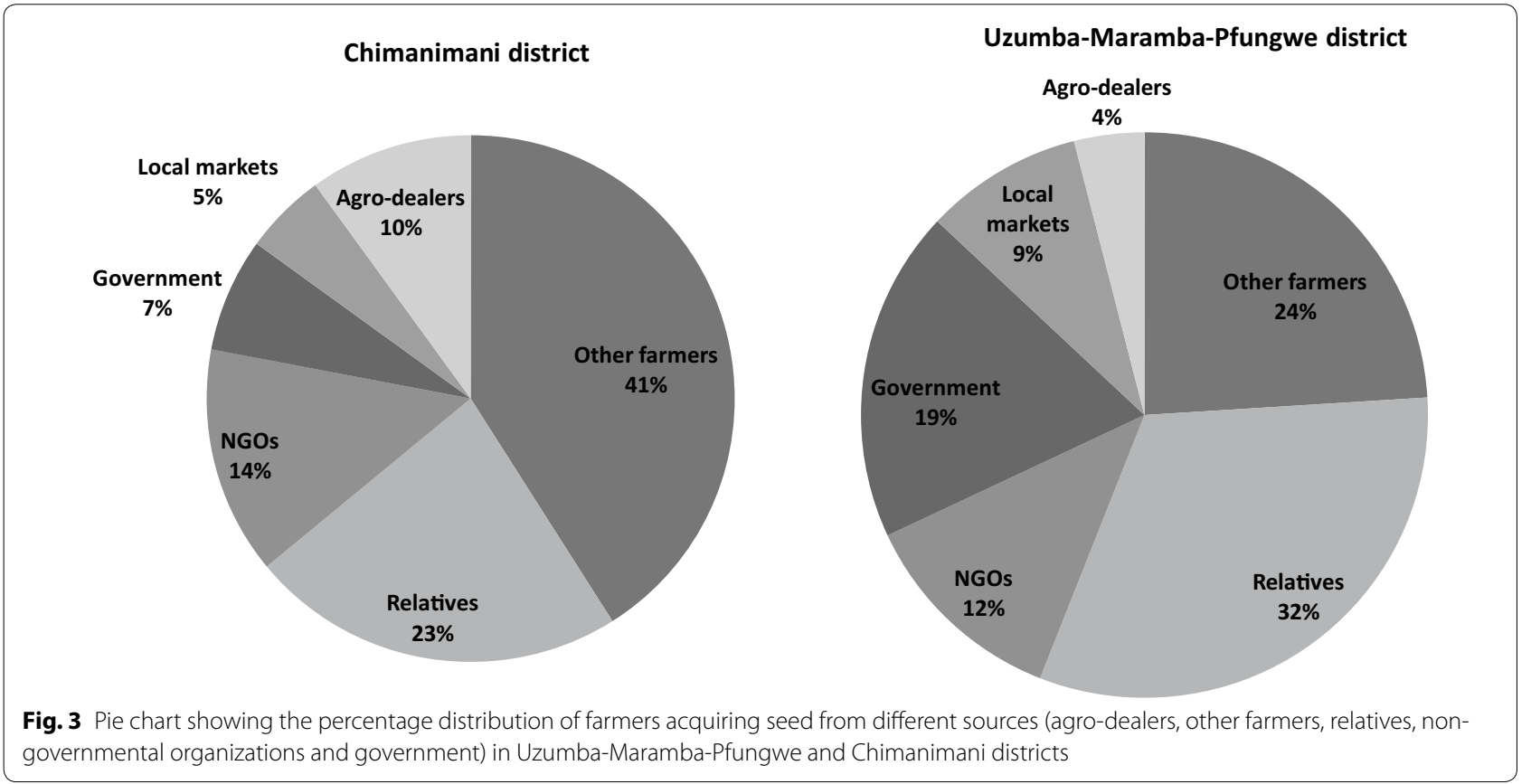



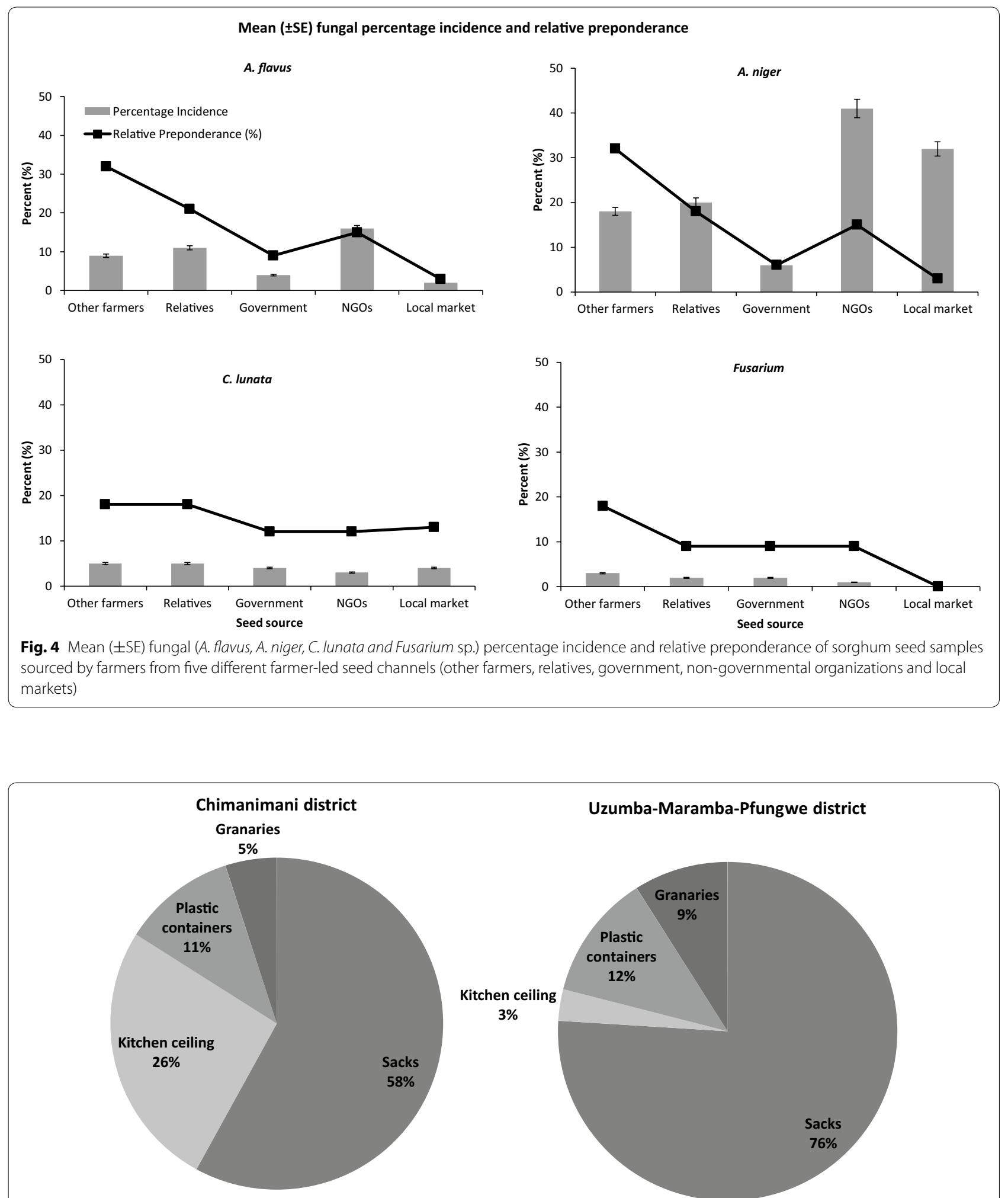

Uzumba-Maramba-Pfungwe district

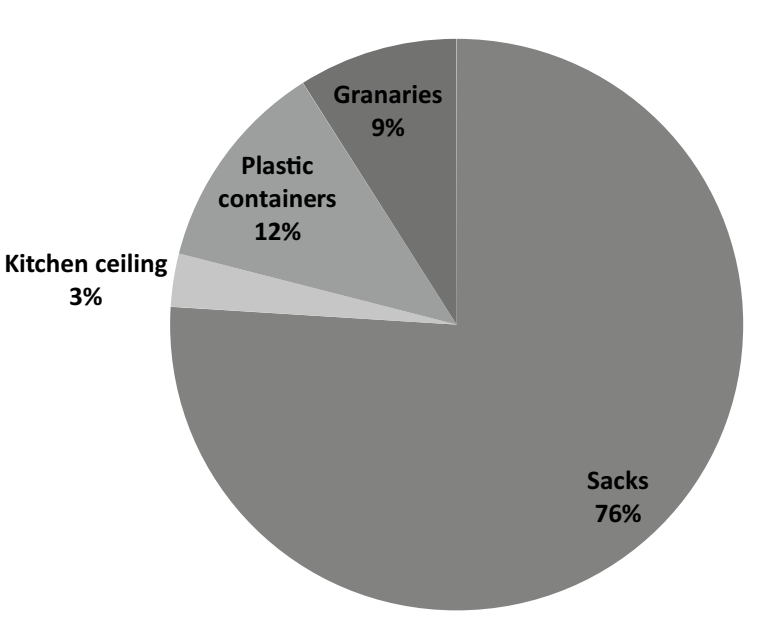

Fig. 5 Proportion of respondents utilizing seed storage facilities 
Seed sourced from 'other farmers' recorded a RP ranging from 0 to $32 \%$ for all fungal species that were screened. Seed samples acquired through other farmers were found stored in sacks, kitchen ceilings, granaries and plastic containers. The fungal mean PI for all screened samples ranged from 4.8 to $12.8 \%$ in sacks, $0-25 \%$ in granaries, $0-15.2 \%$ in kitchen ceilings and $0.4-$ $16.8 \%$ in plastic containers (Table 2). A. flavus recorded the least mean PI for samples stored in granaries and plastic containers, which were significantly lower (LSD, $p \leq 0.05)$ than the mean PI found in samples drawn from sacks and kitchen ceiling. A. niger recorded significantly higher mean PI (LSD, $p \leq 0.05$ ) for samples stored in granaries than the mean PI for samples stored in sacks, kitchen ceilings and plastics containers. C. lunata and Fusarium sp. were absent on seed samples drawn from the granary. C. lunata mean PI was significantly lower (LSD, $p \leq 0.05$ ) than samples coming from kitchen and plastic containers. Fusarium sp. mean PI was significantly lower (LSD, $p \leq 0.05$ ) on samples stored in plastics than samples stored in sacks and kitchen ceilings.

Sorghum seed samples sourced from the 'relatives' were found stored in sacks and plastic containers only
(Table 2). RP for all sorghum samples acquired from relatives ranged from 0 to $21 \%$ for all fungi screened. Mean fungal PI for all screened fungi ranged from 0 to $32.15 \%$ on samples stored in sacks and $0-17.6 \%$ on samples stored in plastic containers. The mean fungal PI was found to be significantly higher (LSD, $p \leq 0.05$ ) for samples stored in sacks than in plastics for A. flavus and $A$. niger. In this category, no fungi detections were found for granary and kitchen ceiling storage facilities.

Sorghum seed sourced from government was found stored in sacks only (Table 2). The RP for all samples sourced through government ranged from 0 to $12 \%$ for all fungi screened. The mean PI for all screened fungi ranged between 0 and $16 \%$. Seed sourced from NGOs was found stored in sacks, kitchen ceilings and granaries (Table 2). RP for all samples ranged from 0 to $15 \%$ for all fungi screened on samples sourced through NGOs. Mean PI for all screened fungi ranged from 0 to $99.2 \%$ for samples from sacks, $0-28.8 \%$ on samples from kitchen ceilings and $0-60.4 \%$ for samples from granaries.

Seed sourced from local markets tested positive for 3 fungal species out of 5 that were tested, with positive samples drawn from sacks and granaries. The overall RP

Table 2 Mean ( \pm SE) germination, moisture content and fungal incidence levels of sorghum seeds sourced and stored under different farmer-led practices

\begin{tabular}{|c|c|c|c|c|c|c|c|}
\hline \multirow[t]{2}{*}{ Seed source and storage } & \multirow[t]{2}{*}{ Germination (\%) } & \multirow[t]{2}{*}{ Moisture (\%) } & \multicolumn{5}{|c|}{ Percentage (\%) incidence levels } \\
\hline & & & A. flavus & A. niger & C. lunata & Fusarium & Penicilium \\
\hline \multicolumn{8}{|l|}{ Other farmers } \\
\hline Sacks & $83 \pm 1.85$ & $9.65 \pm 0.06$ & $12.8 \mathrm{~b}$ & $17.9 \mathrm{~cd}$ & $4.8 \mathrm{abc}$ & $7.9 \mathrm{c}$ & $4.8 \mathrm{a}$ \\
\hline Kitchen & $84 \pm 1.64$ & $10.2 \pm 0.03$ & $11.4 b$ & $15.2 \mathrm{bcd}$ & $13.1 \mathrm{~cd}$ & $6 c$ & 0 \\
\hline Granary & $92 \pm 0.41$ & $10.7 \pm 0.25$ & $3.6 a$ & $25.6 \mathrm{ef}^{1}$ & $\mathrm{Oa}$ & Oa & 0 \\
\hline Plastics & $85 \pm 1.68$ & $9 \pm 0.03$ & $2.4 \mathrm{a}$ & $12.8 \mathrm{bc}$ & $16.8 d$ & $2.4 a b$ & $0.4 b$ \\
\hline \multicolumn{8}{|l|}{ Relatives } \\
\hline Sacks & $64 \pm 4.49$ & $9.2 \pm 0.04$ & $19.45 c$ & $32.15 f^{1}$ & $5.95 \mathrm{abc}$ & $0.4 a$ & 0 \\
\hline Plastics & $45 \pm 3.24$ & $13.3 \pm 0.32$ & $3.8 a$ & $2.4 a$ & $17.6 \mathrm{~d}$ & $7.2 \mathrm{C}$ & 0 \\
\hline \multicolumn{8}{|l|}{ Government } \\
\hline Sacks & $79 \pm 2.75$ & $11 \pm 0.17$ & $11.8 \mathrm{~b}$ & $16 \mathrm{bcd}$ & $4.55 a b c$ & $3.4 b$ & 0 \\
\hline \multicolumn{8}{|l|}{ NGOs } \\
\hline Sacks & $85 \pm 0.59$ & $9.3 \pm 0.19$ & $4.8 \mathrm{a}$ & $99.2 \mathrm{~h}^{1}$ & $1.6 a b$ & $1.6 a$ & 0 \\
\hline Kitchen & - & $10 \pm 0.10$ & $28.8 d^{1}$ & $23.2 \mathrm{de}$ & $10.4 \mathrm{bcd}$ & $0.8 a$ & 0 \\
\hline Granary & $80 \pm 0.81$ & $11.6 \pm 0.16$ & $28.8 d^{1}$ & $60.4 g^{1}$ & $4 a b c$ & $0.4 a$ & 0 \\
\hline \multicolumn{8}{|l|}{ Local market } \\
\hline Sacks & $93 \pm 1.45$ & $11 \pm 0.21$ & $21.6 c$ & $8.8 \mathrm{ab}$ & $4.8 a b c$ & Oa & 0 \\
\hline Granary & - & - & $2.4 \mathrm{a}$ & $32 f^{1}$ & $4 a b c$ & Oa & 0 \\
\hline $\operatorname{LSD}(p \leq 0.05)$ & & 4.4 & 8.4 & 10.4 & 2.6 & 2.6 & \\
\hline
\end{tabular}

LSD (least significant difference) calculates the smallest significant difference between two means enabling direct comparisons between two means from two individual groups. Means followed by the same letter (in columns) are not significantly different at $95 \%$ confidence interval. Formal seed certification sorghum standards for Zimbabwe, germination $80 \%$ and moisture content $12.5 \%$

1 Percentage incidence greater than $25 \%$ 
ranged from 0 to $13 \%$, and the mean PI ranged from 0 to $21.6 \%$ in sacks and $0-32 \%$ in granaries.

\section{Discussion}

The results show that $75 \%$ of farmers surveyed grew sorghum, with $68 \%$ of their seed acquired through farmer-led seed sources (other farmers, relatives and local markets). The observation that farmer-based seed sources are common in smallholder communities is similar to those reported in earlier studies [5, 9, 10, 12, 23]. This confirms the importance of sorghum as an important crop and validates the fact that farmer-led seed systems remain the dominant source of seed in such communities [12].

Farmers used a diversity of seed sources and storage facilities, providing an inherent and resilient seed supply to the farmers. If one seed source or storage facility fails, then alternatives can be utilized. These alternatives give farmers a chance to evolve adaptive pathways that can sustain their seed security [12] and can thus potentially achieve food and nutritional security [7]. The diverse seed sources from which farmers acquire their seed may enable the easy flow of climate-adapted genes from one farmers to the other [34], access to new landraces, the recovery of lost varieties and the renewal or broadening of the genetic base of their seed stock $[17,35]$. Such practices may present smallholder farmers with broader opportunities for coping with extreme abiotic and biotic stressors under climate change $[35,36]$.

Local markets were found to supply seed with the highest germination rate at $93 \%$. Only $13 \%$ of the samples tested positive for A. flavus, A. niger and C. lunata, with Fusarium sp. and Penicillium sp. completely absent. The absence of Fusarium sp., which is the most economically important fungi in sorghum production, further strengthens the importance of local markets as a trusted source of quality sorghum seed. The findings point to good seed production practices by farmers producing for local seed markets. Our results corroborate those of McGuire and Sperling [11] who found that 50.9\% of farmers across six countries (including Zimbabwe) acquired their seed from local markets, with $55 \%$ of the transactions cash based. Farmers are rational beings cognizant of risks associated with planting poor-quality seeds; trade reported at local seed markets thus presents evidence that the source is trustworthy and reputable [24]. The reported frequent use of local markets by farmers clearly comprises an informal certification of this seed channel.

Findings indicated that more than half of the sorghum seed samples were infected with A. flavus, A. niger, $C$. lunata and Fusarium sp. Though the fungal incidence levels were very low, their presence points to potential fungal damage to seed and crops, with associated negative impacts on food security, human and animal health. The study also recorded very high $A$. niger PI in samples originally sourced from NGOs and stored in sacks $(99.2 \%)$ and granaries (60.4\%). There could be a number of factors that influenced these results, including the susceptibility of screened sorghum varieties to fungal infections [37] and handling, transportation and storage conditions (from the origin to the beneficiary in such cases as seed aid) [38].

$A$. flavus and $A$. niger were the most prevalent fungi detected, and their presence indicates health threats to both humans and animals from potential mycotoxin poisoning in sorghum food and feed [39]. Mycotoxin exposure in children causes malnutrition and stunted growth. In addition, mycotoxins in livestock cause high livestock mortality. However, most detections were of low incidence $(<25 \%)$. We suggest that these results indicate both the capability of farmers and their significant management expertise to keep their seed clean.

Seed from other farmers also scored high germination $(>80 \%)$, low moisture content $(<11 \%)$ and low PI of fungal infections $(<26 \%)$, reinforcing the finding that farmer-led seed sources have the capacity to produce seeds of high quality. The findings concur with Louwaars and de Boef [9] who noted that some farmers in smallholder farming community could produce seed of good quality and share with their neighbours. Alverez et al. [40] found smallholder farmers in Cameroon not only producing good-quality seed but also highly knowledgeable about sorghum seed production. The failure of the seed samples acquired through relatives to meet the seed certification standards could be explained by the likelihood that seed and grain are often interwoven in exchange. The chances of grain conversion to seed are even higher during crises or post-crises.

We conclude that farmers have the capacity to effectively produce and exchange amongst themselves seed of good quality that is comparable to or even higher than the standards of formal seed systems. Similar findings have also been reported for other crops, including cowpeas and maize. Biemond et al. [22] for example found that farmer-produced cowpeas seed samples had lower infection frequencies of seed- and soil-borne pathogens than seed-certified and foundation seed samples. In a follow-up study on maize, Biemond et al. [41] found that farmer-produced seed samples were heavily infected with a range of seed-and soil-borne pathogens, although 
control samples produced by a public institution were also heavily infected.

The RP and PI for storage facilities did not give a clear indication of which facility is better suited for storage. There is scope to do further tests with a larger sample size to analyse differences. Variations may have also resulted from the handling of seed and different seed management practices. We found sacks to be the most commonly used storage facility in both districts; these were mainly coated with polythene and had limited free air circulation, thus stimulating fungal infestation. In addition, farmers sometimes recycle the same sacks from year to year and there is a possibility of carrying over the fungal inoculum through sacks. Traditional storage facilities such as the kitchen ceilings and granaries were the least used storage facilities.

\section{Conclusions}

Our findings reveal unequivocally that farmer-led seed systems have the capacity to provide quality sorghum seeds for crop production in Zimbabwe. They channel seeds of reasonable quality within comparable levels to the set certification standards. Such systems not only present opportunities to deliver seed, food and nutritional security in sub-Saharan Africa but also have the potential to provide solutions that are resilient to changing climates. Farmer-led seed systems deserves greater recognition and support from governments and other relevant players in crop production in order to develop a tailored and appropriate seed system that meets the everevolving needs of smallholder farmers in sub-Saharan Africa.

\section{Authors' contributions}

KK developed, designed, implemented, analysed and wrote this manuscript, and he is the major contributor. RW supervised all the research processes and edited the manuscript as main supervisor for KK. CM supervised all the research processes and edited the manuscript as PhD co-supervisor for KK. All authors read and approved the final manuscript.

\section{Author details}

${ }^{1}$ Department of Environmental and Geographical Sciences, University of Cape Town, Rondebosch, Cape Town 7700, South Africa. ${ }^{2}$ Department of Research and Specialist Services, Genetic Resources and Biotechnology Institute, P. O. Box CY550, Causeway, Harare, Zimbabwe. ${ }^{3}$ Department of Research and Specialist Services, Seed Services Institute, P. O. Box CY550, Causeway, Harare, Zimbabwe.

\section{Competing interests}

The authors declare that they have no competing interests.

\section{Availability of data and materials}

The data sets used and/or analysed during the current study are available from the corresponding author on reasonable request.

\section{Ethics approval and consent to participate}

The research was approved by the University of Cape Town, Faculty of Science Research Ethics Committee, under the chairmanship of Dr Richard Hill (email: richard.hill@uct.ac.za). The research followed the UCT code for research involving human subjects, and the code can be accessed on http://www.uct.ac.za/ downloads/uct.ac.za/about/policies/ethicscode.pdf.

\section{Funding}

We are grateful for financial and technical support to the Community Technology Development Organization, the Seed and Knowledge Initiative and Swiss Development Cooperation, and the Genetic Resources and Biotechnology Institute, which helped to host the research in Zimbabwe. This work in based on research supported by the South African Research Chairs Initiative of the Department of Science and Technology and National Research Foundation of South Africa. Any opinion, finding and conclusion or recommendation expressed in this material is that of the author(s) and the NRF does not accept any liability in this regard.

\section{Appendix 1: Seed collection questionnaire}


Household Respondent Data

Ward:

GPS:

Respondent Name: Surname

Gender:

$$
1=\text { Male }
$$

Questionnaire number ...........

Village Name:

Age: $1=$ Less than 25

$2=26-35$

$3=36-45$

$5=$

$45-556=$ greater than 55

Highest formal education attained (circle answer): non-formal education $=1$, primary $=2$,

secondary $=3$, post-secondary $=4$, other $($ specify $)=5 \ldots \ldots$

Section 1: Seed collection

1. List seed samples collected, year last harvested, year and source of original acquisition.

\begin{tabular}{|l|l|l|l|}
\hline Crop (variety) & Year & Year & Where did you source the seed \\
& harvested & originally & from? \\
& & acquired & \\
\hline & & & \\
\hline
\end{tabular}

2. For each crop listed above, record the storage facility and measure the seed moisture.

\begin{tabular}{|l|l|l|}
\hline Crop & Storage facility & $\begin{array}{l}\text { Storage } \\
\text { moisture }\end{array}$ \\
\hline & & \\
\hline
\end{tabular}

3. List any storage pest problems encountered and describe methods used to control and manage the pests

\begin{tabular}{|l|l|l|}
\hline Crop & Storage pests & $\begin{array}{l}\text { Methods used to control or } \\
\text { manage pests }\end{array}$ \\
\hline & & \\
\hline
\end{tabular}

4. For each crop when you select your seed and who does that?

\begin{tabular}{|l|l|l|}
\hline Crop & Selection & Who does it? \\
\hline & & \\
\hline
\end{tabular}

Key: 1. Securing crop stands 2. During harvesting 3. During processing 4. In the granary

5. Others specify ...

Name of the administrator. 


\section{Publisher's Note}

Springer Nature remains neutral with regard to jurisdictional claims in published maps and institutional affiliations.

Received: 24 April 2017 Accepted: 5 July 2017

Published online: 01 December 2017

\section{References}

1. Rockstrom J, Steffen W, Noone K, Persson A, Chapin FS III, Lambin E, Lenton TM, Scheffer M, Folke C, Schellnhuber H, Nykvist B, De Wit CA, Hughes T, van der Leeuw S, Rodhe H, Sorlin S, Snyder PK, Costanza R, Svedin U, Falkenmark M, Karlberg L, Corell RW, Fabry VJ, Hansen J, Walker B, Liverman D, Richardson K, Crutzen P, Foley J. Planetary boundaries: exploring the safe operating space for humanity. Ecol Soc. 2009;14(2):32.

2. Holt-Giménez E, Altieri MA. Agroecology, food sovereignty, and the new green revolution. Agroecol Sustain Food Syst. 2013;37(1):90-102.

3. Altieri MA, Nicholls Cl, Montalba R. Technological approaches to sustainable agriculture at a crossroads: an agroecological perspective. Sustainability. 2017;9:349.

4. Valenzuela H. Agroecology: a global paradigm to challenge mainstream industrial agriculture. Horticulturae. 2016;2:2.

5. Byerlee D, De Janvry A, Sadoulet E, Townsend R, Klytchnikova I. World development report 2008. Agriculture for development. Washington: World Bank; 2007

6. IPES-Food. From uniformity to diversity: a paradigm shift from industrial agriculture to diversified agroecological systems. International Panel of Experts on Sustainable Food systems. (2016). www.ipes-food.org/images/ Reports/UniformityToDiversity_FullReport.pdf. Accessed 29 June 2017.

7. Scoones I, Thompson J. The politics of seed in Africa's green revolution: alternatives and competing pathways. IDS Bull. 2011;42:1-23.

8. Altieri MA, Funes-Monzote FR, Petersen P. Agroecologically efficient agricultural systems for smallholder farmers: contribution to food sovereignty. Agron Sustain Dev. 2011;32:1-13.

9. Louwaars NP, de BoefWS. Integrated seed sector development in Africa: a conceptual framework for creating coherence between practices and policies. J Crop Improv. 2012;26:39-59.

10. Louwaars NP, De Boef WS, Edeme J. Integrated seed sector development in Africa: a basis for seed policy and law. J Crop Improv. 2013;27:186-214.

11. McGuire S, Sperling L. Seed system smallholder farmers use. Food Secur. 2016;8:179-95.

12. Food and Agriculture Organization. Food security indicators. Haiti: Country Profiles; 2010.

13. Louwaars NP. Seeds of confusion: the impact of policies on seed systems. Wageningen: Wageningen University; 2007.

14. Cromwell E, Hansen EF, Turner M. The seed sector in developing countries: a framework for performance analysis. Working paper 65, London, UK: ODI (1992).

15. Almekinders CJM, Louwaars NP, de Bruijn G. Local seed systems and their importance for improved seed supply in developing countries. Euphytica. 1994:78:207-16.

16. Almekinders CJM, Louwaars NP. Farmers'seed production. New approaches and practices. London: ITP Publications; 1999.

17. Almekinders CJM, Louwaars NP. The importance of farmers' seed systems in a functional seed sector. J New Seeds. 2002:4:15-33.

18. Food and Agriculture Organization. Sorghum and millet in human health, FAO Corporate Document Repository; 1994.

19. Alimentarius, Codex. Working paper on mycotoxins in sorghum. Joint FAO/WHO Food Standards Codex Committee on Contaminants in foods; 2011

20. Hadebe ST, Modi AT, Mabhaudhi T. A focus on drought tolerance and water use of cereal crops. J Crop Sci Agron. 2017;203:177-91.

21. United Nations Industrial Development Organization, (undated) Project on enhanced value addition and strengthening value chains in the Greater Bahr el Ghazal Region: Framer's training manual on post harvest management of sorghum groundnut and rice. Funded by European Union. https://europa.eu/capacity4dev/file/31677/ download?token=HHL_plQp. Accessed 29 July 2017.
22. Biemond PC, Oguntade O, Lava Kumar P, Stomph TJ, Termorshuizen AJ, Struik PC. Does the informal seed system threaten cowpea seed health? Crop Prot. 2013;43:166-74.

23. Challinor A, Wheeler T, Garforth C, Craufurd P, Kassan A. Assessing the vulnerability of food crop system in Africa to climate change. Clim Change. 2007:83:381-99.

24. Sperling L. Addressing seed security in disaster response: linking relief with development, overview. Cali: CIAT; 2004.

25. Williams RJ, Rao KN. A review of sorghum grain molds. Trop Pest Manag. 1981;27:200-11.

26. Mpofu LT, McLaren NW. Ergosterol concentration and variability in genotype-by-pathogen interaction for grain mold resistance in sorghum. Planta. 2014;240:239-50.

27. Levic TJ, Stankovic SZ, Krnjaja VS, Bocarov-Stancic SA. Fusarium species: the occurrence and importance in agriculture of Serbia. Mat Srp Proc Nat Sci. 2009:116:33-46.

28. Rocha ME, Freire FD, Maia FE, Guedes MI, Rondina D. Mycotoxins and their effects on human and animal health. Food Control. 2014;36:159-65.

29. Kramarenko V, Engstrom L, Verdier G, Fernandez G, Erik Oppers S, Hughes R, McHugh J, Coats W. Zimbabwe: challenges and policy options after hyperinflation, International Monetary Fund, Washington, D.C. USA (2010). https://www.imf.org/external/pubs/ft/dp/2010/afr1003.pdf. ISBN 978-1-58906-997-8. Accessed 29 June 2017.

30. Mugandani R, Wuta M, Makara A, Chipindu B. Re-classification of agroecological regions of Zimbabwe inconformity with climate variability and change. Afr Crop Sci J. 2012;20:361-9.

31. Chikodzi D, Zinhiva H, Simba FM, Murwendo T. Reclassification of agro-ecological zones in Zimbabwe - the rationale, methods and expected benefits: the case of Masvingo Province. J Sustain Dev Afr. 2013;15:104-16.

32. ISTA. International rules for testing. Zurich: ISTA; 2016.

33. Rao KN, Hanson J, Dulloo EM, Kakoli G, Nowell D, Larinde M. Manual for seed handling in genebanks. Rome: Biovers Int; 2006.

34. Howden MS, Soussana JF, Tubiello FN, Chhetri N, Dunlop M, Meinke $\mathrm{H}$. Adapting agriculture to climate change. Natl Acad Sci USA. 2007;104:19691-6.

35. Deletre M, McKey DB, Hodkinson TR. Marriage exchanges, seed exchanges, and the dynamics of manioc diversity. Natl Acad Sci. 2011;108:18249-54.

36. Lin BB. Resilience in agriculture through crop diversification: adaptive management for environmental change. Biosciences. 2011;61:183-93.

37. Cuevas Hugo E, Prom Louis K, Thomas Isakeit, Ghada Radwan. Assessment of sorghum germplasm from Burkina Faso and South Africa to identify new sources of resistance to grain mold and anthracnose. Crop Prot. 2016;79:43-50

38. Bhat RV. Mould deterioration of agricultural commodities during transit: problems faced by developing countries. Int J Food Microbiol. 1988;7:219-25

39. Sreenivasa MY, Dass RS, Janardhana GR. Survey of postharvest fungi associated with sorghum grains produced in Karnataka (INDIA). J Plant Prot Res. 2010:50:335-9.

40. Alverez N, Garineb E, Khasahc C, Douniasd E, Hossaert-McKeya M, McKeya D. Farmers' practices, meta-population dynamics, and conservation of agricultural biodiversity on-farm: a case study of sorghum among Duupa in Sub-Sahelian Cameroon. Biol Conserv. 2005;121:533-43.

41. Biemond P, Oguntade O, Kumar PL, Stomph TJ, Termorshuizen AJ, Struik PC. Health of farmer-saved maize seed in north-east Nigeria. Eur J Plant Pathol. 2013;3:563-72.

42 Gliessman SR. Agroecology: the ecology of sustainable food systems. 2nd ed. New York: CRC Press; 1998. ISBN0-8493-2845-4

43 McGuire S, Sperling L. Making seed systems more resilient to stress. Glob Environ Change. 2013;23:644-53. 